\title{
Antibodies against Mycobacterium avium subspecies paratuberculosis in Cattle of Indore District in Madhya Pradesh
}

\author{
S.D. Audarya ${ }^{1}$, M. Singh ${ }^{2,3}$, K.K. Chaubey ${ }^{2,4}$, S. Gupta ${ }^{2,4}$, R. Sikrodia ${ }^{1}$, \\ D. Chhabra ${ }^{1}$, R. Gangil ${ }^{1}$, S. Matoli ${ }^{1}$, R. Sharda ${ }^{1}$, S.V. Singh ${ }^{2,4}$
}

10.18805/IJAR.B-4773

\begin{abstract}
Background: Paratuberculosis or Johne's disease in domestic livestock population is caused by the bacteria, Mycobacterium avium subspecies paratuberculosis. The disease in cattle is characterized by chronic granulomatous enteritis leading to diarrhoea (intermittent or continuous) followed by weakness and emaciation in the affected animals. This research aimed to test cattle population, serologically, for detecting level of Mycobacterium avium subspecies paratuberculosis infection.

Methods: In the present study, a total of 180 serum samples from individual cattle of Indore district in Madhya Pradesh tested in a serological test, indigenous enzyme linked immunosorbent assay for detection of antibodies against Mycobacterium avium subspecies paratuberculosis.

Result: A total of 49 cattle (27.2\%) were found positive in the test for the bio-presence of Mycobacterium avium subspecies paratuberculosis infection.
\end{abstract}

Key words: Cattle, Indirect enzyme linked immunosorbent assay, Paratuberculosis.

\section{INTRODUCTION}

Paratuberculosis or Johne's disease (JD) is caused by the bacterial agent Mycobacterium avium subspecies paratuberculosis (MAP). The disease is characterized by a long-lasting enteritis of large ruminants (Hassan et al., 2019). Besides infecting sheep and goats, it also infects wild ruminants (bison, blue bulls, deer) and human beings (Radostits et al., 2000; Biswal et al., 2020). The $20^{\text {th }}$ livestock census of India recorded a total livestock population of 536.76 million (Cattle-193.46 million (36.04\%), Goats-148.88 million (27.74\%), Buffalo-109.85 million (20.47\%), Sheep74.26 million (13.83\%), Pigs-9.06 million (1.69\%) and others i.e. Mithun, Yaks, Horses, Ponies, Mules, Donkeys and Camels $(0.23 \%)$. Cattle (indigenous, exotic and crossbred) are used in producing milk and utilised for draft purposes in the field and for transportation in the country. Female cattle (cow population-145.91 million) were increased by $18.6 \%$ over previous census (122.9 million) indicating increased interest of livestock owners in rearing cattle for milk (VIKASPEDIA, 2021). Milk production in Madhya Pradesh stood at 17.2 billion litres. Cow milk dominated the total milk production in the region in 2019. Dairy market in the state is separated into 18 different major product segments (raw, fermented, value added products from milk) (IMARC, 2019).

So, regular testing of livestock population for monitoring their health status is essential to prevent and control animal infectious diseases and thereby contain losses to dairy sector. Paratuberculosis is diagnosed tentatively clinically (history of chronic diarrhoea that is generally untreatable and extreme emaciation in affected bovines) and also definitively by laboratory diagnostic methods such as acid fast staining (AFS) of faecal material and further confirmation
${ }^{1}$ Department of Veterinary Microbiology, College of Veterinary Science and Animal Husbandry, Nanaji Deshmukh Veterinary Science University, Mhow, Indore-453 441, Madhya Pradesh, India. ${ }^{2}$ Veterinary Microbiology Laboratory, Division of Animal Health, Central Institute for Research on Goats, Makhdoom-Farah-281 122, Mathura, Uttar Pradesh, India.

${ }^{3}$ Centre for Interdisciplinary Biomedical Research, Adesh University, Bathinda-151 009, Punjab, India.

${ }^{4}$ Department of Biotechnology, GLA University, Chaumuhan, Mathura-281 406, Uttar Pradesh, India.

Corresponding Author: S.D. Audarya, Department of Veterinary Microbiology, College of Veterinary Science and Animal Husbandry, Nanaji Deshmukh Veterinary Science University, Kuthuliya, Rewa486 001, Madhya Pradesh, India.

Email: asd_vet@yahoo.com.

How to cite this article: Audarya, S.D., Singh, M., Chaubey, K.K., Gupta, S., Sikrodia, R., Chhabra, D., Gangil, R., Matoli, S., Sharda, R. and Singh, S.V. (2022). Antibodies against Mycobacterium avium subspecies paratuberculosis in Cattle of Indore District in Madhya Pradesh. Indian Journal of Animal Research. DOI: 10.18805/ IJAR.B-4773.

Submitted: 14-09-2021 Accepted: 24-12-2021 Online: 29-01-2022

by agent isolation from faeces of infected animal, serological testing by using agar gel immunodiffusion (AGID), complement fixation test (CFT), Enzyme linked immunosorbent assay (ELISA), fluorescent antibody technique (FAT), dot-ELISA and molecular methods such as polymerase chain reaction (PCR). Rectal biopsy or scraping and lymph node biopsy followed by AFS, intradermal johnin and intravenous johnin testing are also conducted for the diagnosis (Singh et al., 2016b; Chakrabarti, 2003). In the present investigation, 
indigenously developed ELISA is used for screening serum samples of cattle to evaluate antibody response against MAP infection.

\section{MATERIALS AND METHODS Geographic location}

Indore district (latitude-22 $39^{\prime} 59.99^{\prime \prime}$ N 7544'59.99 E) is one of the important districts of Madhya Pradesh state in India. It lies in an average altitude of 550 meter above sea level. The district is located in semi-arid zone towards the southern edge of Malwa. The region (predominantly has black soil) lies in rain-shadow area of Western Ghats (Kawadia and Tiwari, 2017). It receives majority of its rains through SouthWest monsoon. Madhya Pradesh is landlocked and has no international border. It is surrounded by Uttar Pradesh, Chhattisgarh, Maharashtra, Gujarat and Rajasthan (Britannica, 2020).

\section{Serum samples}

Blood samples from 180 cattle (Crossbred, non-descript) of Indore and adjacent area were collected randomly irrespective of their clinical status for Paratuberculosis infection and separated serum stored in the deep freezer $\left(-40^{\circ} \mathrm{C}\right)$ in the Microbiology Department. These serum samples were transported to Central Institute for Research on Goats (CIRG), Farah under cold chain conditions and stored at deep freezing conditions $\left(-20^{\circ} \mathrm{C}\right)$. The testing was done during the year 2016-2018.

\section{Indigenous ELISA}

The indigenous ELISA (iELISA) for detection of serum antibodies against Johne's disease or MAP developed in the Veterinary Microbiology Laboratory, Animal Health Division, Central Institute for Research on Goats (CIRG), Farah was employed in the present investigation and briefly described (Audarya et al., 2018).

\section{Antigen preparation}

Antigen was prepared from native highly pathogenic field isolates of MAP (S5) recovered from a terminal case (in lateral recumbency due to weakness and debility) of Johne's disease in a Jamunapari goat (which later succumbed and died) located at CIRG farm herds. Antigen was prepared from this S5 'Bison type' strain MAP at 16th passage level. Growth was inactivated $\left(72^{\circ} \mathrm{C}\right.$ for 2 hours $)$ and pelleted at $10,000 \mathrm{~g}$ for $20 \mathrm{~min}$. at $40^{\circ} \mathrm{C}$. Pellet was given 3 washing in $0.01 \mathrm{M}$ phosphate buffered saline (PBS) $\mathrm{pH} 7.2$. After $3^{\text {rd }}$ washing pellet was suspended in sterilized normal saline solution in ratio of $0.2 \mathrm{~g}$ of wet cell weight $/ \mathrm{ml}$, in $30 \mathrm{ml}$ and treated to ultrasonic disruption (sonication) at 100 watts $(15 \mathrm{~Hz})$ for $20 \mathrm{~min}$. in ice slurry giving 20 cycles of 30 seconds and 30 seconds rest after each cycle. The sonicate was centrifuged $\left(10,000 \mathrm{rpm}\right.$ for $30 \mathrm{~min}$ at $\left.4^{\circ} \mathrm{C}\right)$, dispensed and stored at $-20^{\circ} \mathrm{C}$. Protein concentration was also estimated (Lowry et al., 1951; Sevilla et al., 2005; Personal communication with R.J. Whittington).

\section{Coating of microplates with antigen}

Lysate (sonicated whole cell) was centrifuged, standardized and used in coating. $100 \mu \mathrm{l}$ of working antigen (at $0.1 \mu \mathrm{g} /$ well of microtiter plate) was added in each well of microtiter plate. Antigen added plates were placed at $-4^{\circ} \mathrm{C}$ for overnight.

\section{Blocking of wells}

Overnight antigen coated plates were brought to room temperature and washed once with $1 \times$ PBS $+0.05 \%$ Tween 20 . Wells of the plates were blocked with skimmed milk $(100 \mu \mathrm{l}$ of $3 \%$, in $1 \times \mathrm{PBS})$ and plates were incubated $\left(37^{\circ} \mathrm{C}\right.$ for $1 \mathrm{~h}$ ).

\section{Testing of serum samples by iELISA}

After blocking plates were brought to room temperature and washed thrice with $1 \times$ PBST. 1:50 dilution serum samples were used. Thereafter $100 \mu \mathrm{l}$ of diluted anti-species horseradish peroxidase conjugate (Sigma) (1:5000 dilution) was added and incubated for $1 \mathrm{~h}$ at $37^{\circ} \mathrm{C}$. On completion of incubation, plates were washed four times with $1 \times$ PBST. Thereafter, in each well $100 \mu \mathrm{l}$ of substrate was added ophenylenediamine dihydrochloride (OPD) at $5 \mathrm{mg} / \mathrm{plate}$ concentration in substrate buffer, $\mathrm{pH}-5$ ) and plates were incubated at room temperature in the dark for 3-5 $\mathrm{min}$. Culture positive and negative samples of animals were used as positive and negative controls, respectively. Blank was also run. ELISA reader was used to record absorbance at $450 \mathrm{~nm}$.

\section{Interpretation}

The following formula was used to transform Optical densities (OD) to sample to positive ratios (S/P ratio) (OD value of test serum sample - OD value of negative control)/ (OD value of positive control - OD value of negative control). Thereafter as per the S/P ratio, if S/P ratio was in between 0.00-0.09- animals were negative, $0.10-0.24$ - suspected, $0.25-0.39$ - low positive, $0.40-0.99$ - positive and strong positive (1.0-10.00) for Johne's disease status. For biopresence of MAP infection, those animals falling in 0.40 to 10.00 were considered positive (Collins, 2002).

\section{RESULTS AND DISCUSSION}

OD values recorded (after testing cattle serum samples in iELISA for the presence of antibodies to MAP infection) were used to calculate S/P ratio. Of the total 180 cattle, 2, 47, 22, 30 and 79 demonstrated S/P ratio in between $1-10,0.40$ $0.99,0.25-0.39,0.10-0.24$ and $0.00-0.09$, respectively. Results of the investigation are presented in Table 1, 2 and 3.

Johne's disease is caused by Mycobacterium avium subspecies paratuberculosis in large ruminants. It causes chronic progressive diarrhea in cattle and buffalo population. It is also thought to be associated with Crohn's disease and producing cancer in human beings (Pierce, 2018). The disease in large ruminants is characterized by chronic enteritis followed by emaciation. Economic impact of 
Antibodies against Mycobacterium avium subspecies paratuberculosis in Cattle of Indore District in Madhya Pradesh

Table 1: Cattle serum samples tested low positive, positive, suspected, strong positive in indigenous enzyme linked immunosorbent assay for MAP infection.

\begin{tabular}{|c|c|c|c|c|c|c|c|}
\hline Sample & $\mathrm{S} / \mathrm{P}$ ratio & Sample & $\mathrm{S} / \mathrm{P}$ ratio & Sample & $\mathrm{S} / \mathrm{P}$ ratio & Sample & $\mathrm{S} / \mathrm{P}$ ratic \\
\hline Low positive & $\mathrm{N}=22$ & & & & & & \\
\hline 3 & 0.262687 & 19 & 0.537313 & 85 & 0.453731 & 50 & 0.107463 \\
\hline 6 & 0.301493 & 22 & 0.516418 & 86 & 0.501493 & 52 & 0.238806 \\
\hline 10 & 0.289552 & 30 & 0.585075 & 88 & 0.8 & 59 & 0.110448 \\
\hline 16 & 0.355224 & 32 & 0.540299 & 92 & 0.499244 & 97 & 0.111952 \\
\hline 21 & 0.253731 & 33 & 0.659701 & 94 & 0.499244 & 99 & 0.199697 \\
\hline 23 & 0.289552 & 39 & 0.438806 & 95 & 0.711044 & 101 & 0.133132 \\
\hline 42 & 0.358209 & 43 & 0.453731 & 100 & 0.532526 & 115 & 0.14826 \\
\hline 45 & 0.250746 & 44 & 0.432836 & 103 & 0.599092 & 117 & 0.118003 \\
\hline 48 & 0.337313 & 46 & 0.450746 & 104 & 0.559758 & 124 & 0.214826 \\
\hline 53 & 0.298507 & 47 & 0.528358 & 112 & 0.744327 & 125 & 0.121029 \\
\hline 57 & 0.391045 & 51 & 0.441791 & 113 & 0.426626 & 126 & 0.136157 \\
\hline 60 & 0.298507 & 55 & 0.486567 & 114 & 0.456884 & 128 & 0.239032 \\
\hline 62 & 0.391045 & 56 & 0.456716 & 120 & 0.487141 & 129 & 0.19062 \\
\hline 70 & 0.295522 & 58 & 0.626866 & 121 & 0.459909 & 132 & 0.130106 \\
\hline 79 & 0.274627 & 61 & 0.710448 & 152 & 0.459909 & 137 & 0.151286 \\
\hline 87 & 0.313433 & 63 & 0.429851 & 165 & 0.780635 & 143 & 0.130106 \\
\hline 105 & 0.329803 & 64 & 0.447761 & 173 & 0.402421 & 149 & 0.118003 \\
\hline 109 & 0.299546 & 65 & 0.570149 & 174 & 0.420575 & 156 & 0.111952 \\
\hline 110 & 0.293495 & 67 & 0.731343 & Suspected & $N=30$ & 160 & 0.187595 \\
\hline 123 & 0.293495 & 68 & 0.656716 & 4 & 0.101493 & 164 & 0.114977 \\
\hline 127 & 0.387292 & 69 & 0.465672 & 5 & 0.232836 & 166 & 0.130106 \\
\hline 145 & 0.378215 & 71 & 0.507463 & 11 & 0.185075 & 175 & 0.229955 \\
\hline Positive & $N=47$ & 75 & 0.447761 & 13 & 0.18806 & 180 & 0.166415 \\
\hline 8 & 0.650746 & 76 & 0.444776 & 31 & 0.158209 & Strong positive & $N=2$ \\
\hline 14 & 0.480597 & 77 & 0.441791 & 34 & 0.235821 & 7 & 1.044776 \\
\hline 15 & 0.961194 & 80 & 0.522388 & 40 & 0.176119 & 24 & 1.062687 \\
\hline
\end{tabular}

Table 2: Cattle serum samples tested negative in indigenous enzyme linked immunosorbent assay for MAP infection.

\begin{tabular}{|c|c|c|c|c|c|c|c|}
\hline Sample & S/P ratio & Sample & S/P ratio & Sample & $\mathrm{S} / \mathrm{P}$ ratio & Sample & S/P ratio \\
\hline Negative & $\mathrm{N}=79$ & 66 & -0.05373 & 116 & 0.051437 & 151 & 0.045386 \\
\hline 1 & -0.04776 & 72 & -0.0149 & 118 & 0.08472 & 153 & 0 \\
\hline 2 & 0.089552 & 73 & 0.071642 & 119 & 0.033283 & 154 & 0.006051 \\
\hline 9 & -0.01791 & 74 & 0.01791 & 122 & 0.072617 & 155 & 0.099849 \\
\hline 12 & 0.020896 & 78 & -0.00597 & 130 & 0.08472 & 157 & 0.051437 \\
\hline 17 & -0.05373 & 81 & -0.03582 & 131 & 0.018154 & 158 & 0.093797 \\
\hline 18 & 0.068657 & 82 & -0.02985 & 133 & 0.078669 & 159 & 0.066566 \\
\hline 20 & 0.089552 & 83 & -0.0209 & 134 & -0.03328 & 161 & 0.024206 \\
\hline 25 & 0.01194 & 84 & -0.06866 & 135 & 0.051437 & 162 & 0.039334 \\
\hline 26 & 0.056716 & 89 & -0.04478 & 136 & 0.072617 & 163 & 0.048411 \\
\hline 27 & 0.038806 & 90 & -0.01194 & 138 & 0.04236 & 167 & 0.057489 \\
\hline 28 & 0.047761 & 91 & -0.0121 & 139 & -0.02421 & 168 & 0.045386 \\
\hline 29 & 0.080597 & 93 & 0.08472 & 140 & 0.066566 & 169 & 0.036309 \\
\hline 35 & -0.02388 & 96 & -0.02421 & 141 & 0.054463 & 170 & -0.0121 \\
\hline 36 & -0.00597 & 98 & 0.048411 & 142 & 0.030257 & 171 & -0.04841 \\
\hline 37 & 0.008955 & 102 & -0.06051 & 144 & 0.087746 & 172 & 0.006051 \\
\hline 38 & 0.01194 & 106 & 0.04236 & 146 & 0.027231 & 176 & -0.00605 \\
\hline 41 & -0.02388 & 107 & -0.01513 & 147 & 0.027231 & 177 & 0.024206 \\
\hline 49 & 0.023881 & 108 & 0.093797 & 148 & 0.075643 & 178 & 0.054463 \\
\hline 54 & 0.089552 & 111 & 0.036309 & 150 & -0.01513 & 179 & 0.009077 \\
\hline
\end{tabular}


Table 3: Cattle serum samples divided into different groups according to the outcome of test results for bio-presence of MAP infection.

\begin{tabular}{lccc}
\hline Outcome & $\begin{array}{c}\text { S/P } \\
\text { ratio }\end{array}$ & $\begin{array}{c}\text { Number } \\
\text { of samples }\end{array}$ & Percentage \\
\hline Strong positive & $1-10$ & 2 & 1.11 \\
Positive & $0.40-0.99$ & 47 & 26.11 \\
Low positive & $0.25-0.39$ & 22 & 12.22 \\
Suspected & $0.10-0.24$ & 30 & 16.67 \\
Negative & $0.00-0.09$ & 79 & 43.89 \\
\hline
\end{tabular}

paratuberculosis in cattle was well documented. To reduce the economic impact of paratuberculosis, it is inevitable to know the degree of the MAP infection in cattle for implementing cost-effective disease prevention and control measures (Hasonova and Pavlik 2006; Garcia and Shallo, 2015). In India MAP infection was reported in livestock population (Audarya et al., 2013; Audarya et al., 2016; Matoli et al., 2018; Sharma et al., 2020). The selection of the diagnostic test for Paratuberculosis was based on many factors (Salem et al., 2013). Various serological and molecular methods have been used for the diagnosis of Paratuberculosis in India and abroad (Gumussoy et al., 2015; Abdelaal et al., 2019).

Hence, in the present investigation, 180 serum samples from cattle from Indore district of Madhya Pradesh in India were investigated for bio-presence of MAP infection in iELISA developed at CIRG. Previously, serological positive percentages of $15.14 \%$ and $37.7 \%$ in ELISA were detected in cattle from Karnataka and West Bengal in India (Gupta et al., 2012; Bhutediya et al., 2017). In the present study, a total of $49(27.22 \%)$ cattle tested positive for bio-presence of MAP infection. Breed wise susceptibility for MAP infection was not widely studied. In Pakistan, in Sahiwal cattle breed 3-18 times higher chances of disease was found compared to Cholistani breed of cattle (Hussain et al., 2018). Majority of the cattle investigated in the present study were either crossbred or non-descript adult animals so it was unable to throw light on the susceptibility of specific cattle breed and also risk factors associated with sero-positivity to JD (Sun et al., 2015; Garg et al., 2016). However, in future such studies can be planned in the state of Madhya Pradesh where 3 cattle breeds (Malwi, Kenkatha and Nimari), crossbred and non-descript indigenous cattle are reared for milch and draft purposes.

Bio-load of MAP in the livestock population of India is very high ( $23 \%$ to $43 \%)$. Large ruminants had higher bioload $(36 \%-43 \%)$ of MAP than small ruminants $(23 \%-41 \%)$. Among ruminants, cattle have highest bio-load of MAP and goats have the lowest (Chaubey et al., 2017). MAP causes chronic infection in cattle and also exhibit latency (Nielsen et al., 2013). Cattle provides a significant proportion of milk produced in India. MAP is an important food borne pathogen in India. MAP organisms are shed in the milk of infected cattle too. MAP may also provide foundation for establishing diabetes (Singh et al., 2014). Besides, being in contact with infected cattle herds and consumption of MAP contaminated milk or products made from such milk, humans may catch infection from showers and river aerosols too (Rhodes et al., 2014). However, in cattle, neonates and young animals are infected primarily by the fecal-oral route (Rathnaiah et al., 2017). In India, presence of MAP was reported in various species of animals and their products, human beings and environmental resources from 1960 to till date (Singh et al., 2016a). The results of the present study indicated bio-presence of MAP infection (27.2\%) amongst cattle population of the Indore district. The findings of the study will be helpful in implementing prevention and control strategies against Paratuberculosis in Madhya Pradesh (Boschiroli and Thorel, 2010; Geraghty et al., 2014; Whittington et al., 2019). Madhya Pradesh has shared border with many states. So, animal certification and transportation must be regulated with strict measures regarding movement of animals for trade, fairs and other purposes.

Elimination of the infectious agent from the farm by test and slaughter or culling of positive cattle is not practiced in most of the cases due to economical and ethical reasons in India. Hence, disease transmission from infected animals to susceptible young ones must be stopped by using appropriate management practices (such as vaccination of healthy cattle, better hygiene at farms, segregation and treatment of affected cattle and disposal of the contaminate waste) to empower livestock owners (Pradere, 2014). Present vaccine available in India against Paratuberculosis (Bio-JD, having both preventive and prophylactic value) is an inactivated vaccine but it is not that popular amongst livestock owners due to their unawareness about the disease. India has continuously implemented vaccination programme against Foot-and-Mouth disease. Very recently vaccination against Brucellosis is also envisioned for susceptible livestock. Considering the widespread occurrence of Paratuberculosis in India and its economic implications to the livestock owners and industry, regular sero-surveillance campaigns and agent isolation and nationwide Paratuberculosis control strategies like immunizing susceptible cattle/livestock population against the disease in India as well as in the state of Madhya Pradesh is the need of the present times.

\section{CONCLUSION}

In the present investigation, indigenously developed ELISA was used for screening serum samples of cattle to evaluate antibody response against MAP infection. The results of the study indicate $27.22 \%$ bio-presence of MAP infection in cattle population in the region of Madhya Pradesh. In India, there is an indigenously developed vaccine which is both of prophylactic and therapeutic in nature. Hence, vaccination against paratuberculosis is recommended for the susceptible livestock population of the area in the state to contain economic losses to the livestock owners. 


\section{ACKNOWLEDGEMENT}

Authors are thankful to the staff of the laboratories for providing timely help.

\section{REFERENCES}

Abdelaal, A.M., Elgioushy, M.M., Gouda, S.M., El-Adl, M.M. and Hashish, E.A. (2019). Hematobiochemical and molecular markers (IS900) of cattle infected with Johne's disease in Egypt. Slovenian Veterinary Research. 56 (Suppl. 22): 421-431.

Audarya, S.D., Chaubey, K., Gupta, S., Kumar, N., Yadav, D.S., Chhabra, D., Sharda, R., Garg, U.K. and Singh, S.V. (2013). Investigation on bovine Johne's disease in an organized dairy farm of Mhow in Madhya Pradesh. International Journal of Current Research. 5(10): 2895-2897.

Audarya, S.D., Chhabra, D., Sahzad, Singh, M., Stephen, B.J., Chaubey, K.K., Gupta, S., Dhama, K. and Singh, S.V. (2016). Bio-incidence of bovine Johne's disease in dairy buffaloes in central and north India using sensitive goat based indigenous ELISA kit and traditional tests. Journal of Experimental Biology and Agriculture Sciences. 4(5): 525-532.

Audarya, S.D., Singh, M., Stephen, B.J., Sahzad, Chaubey, K.K., Gupta, S., Pachoori, A., Jayraman, S., Aseri, G.K., Sohal, J.S., Bhatia, A.K. and Singh, S.V. (2018). Status of Johne's disease in buffalo population of Malwa region using goat based indigenous ELISA kit. Buffalo Bulletin. 37(1): 9-16.

Bhutediya, J.M., Dandapat, P., Chakrabarti, A., Das, R. and Nanda, P.K. (2017). Prevalence of paratuberculosis in organized and unorganized dairy cattle herds in West Bengal, India. Veterinary World. 10(6): 574-579.

Biswal, S., Rath, A.P., Singh, S.V., Sahoo, N., Gupta, S., Singh, M. and Chaubey, K.K. (2020). Detection of Mycobacterium avium subsp. paratuberculosis (MAP) from subclinical caprine Paratuberculosis cases of Odisha. Indian Journal of Animal Research. 54(6): 709-712.

Boschiroli, M.L. and Thorel, M.F. (2010). Paratuberculosis. In Lefevre, P.C., Blancou, J., Chermette, R. and Uilenberg, G., editors. Infectious and Parasitic diseases of livestock. 11, rue Lavoisier F-75008, Paris: Editions Medicales Internationales. 1097-1107.

Britannica (2020). Madhya Pradesh. Available: https:// www.britannica.com/place/Madhya-Pradesh. Accessed: 06/04/2021.

Chakrabarti, A. (2003). A textbook preventive veterinary medicine. 3rd edition. New Delhi: Kalyani publishers.

Chaubey, K.K., Singh, S.V., Gupta, S., Singh, M. and Sohal, J.S. (2017). Mycobacterium avium subspecies paratuberculosis -an important food borne pathogen of high public health significance with special reference to India: an update. Veterinary Quarterly. 37(1): 282-299.

Collins, M.T. (2002). Interpretation of a commercial bovine paratuberculosis enzyme-linked immunosorbent assay by using likelihood ratios. Clinical and Diagnostic Laboratory Immunology. 9(6): 1367-1371.

Garcia, A.B. and Shallo, L. (2015). Invited review: the economic impact and control of paratuberculosis in cattle. Journal of Dairy Science. 98(8): 5019-5039.
Garg, R., Patil, P.K., Sharma, S., Singh, S.V. and Sandhu, K.S. (2016). Risk factors associated with sero-positivity to Johne's disease in Indian Dairy herds. Indian Journal of Animal Science. 86(3): 243-249.

Geraghty, T., Graham, D.A., Mullowney, P. and More, S.J. (2014). A review of bovine Johne's disease control activities in 6 endemically infected countries. Preventive Veterinary Medicine. 116(1-2): 1-11.

Gumussoy, K.S., Ica, T., Abay, S., Aydin, F. and Hizilisoy, H. (2015). Serological and molecular diagnosis of paratuberculosis in dairy cattle. Turkish Journal of Veterinary and Animal Sciences. 39: 147-153.

Gupta, A., Rani, S.M., Agrawal, P. and Gupta, P.K. (2012). Seroprevalence of paratuberculosis (Johne's disease) in cattle population of south-western Bangalore using ELISA kit. Open Journal of Veterinary Medicine. 2: 196-200.

Hasonova, L. and Pavlik, I. (2006). Economic impact of paratuberculosis in dairy cattle herds: a review. Veterinary Medicine. 51(5): 193-211.

Hassan, N., Randhawa, C.S., Narang, D., Singh, S.V., Sharma, S. and Singh, S. (2019). Bio-incidence and bio-type of Mycobacterium avium subspecies paratuberculosis in diarrheic dairy and cattle and buffaloes of Punjab area in India. Indian Journal of Animal Research. 53(7): 926-931.

Hussain, S.M., Javed, M.T., Rehman, A.U., Rizvi, F. and Qamar, M. (2018). Prevalence of paratuberculosis in cattle and buffaloes in Punjab Pakistan. Pakistan Journal of Agricultural Science. 55(2): 427-432.

I.M.A.R.C. (2019). Dairy industry in Madhya Pradesh: Market size, growth, prices, segments, cooperatives, private dairies, procurement and distribution. Available: https:// www.imarcgroup.com/dairy-industry-madhya-pradesh\#: : text $=\ln \% 202019 \% 2 \mathrm{C} \% 20$ the $\% 20$ milk\%20production, largest $\% 20$ dairy $\% 20$ market $\% 20$ in $\% 20$ India.andtext $=$ The $\% 20$ report's $\% 20$ analysis $\% 20$ concludes $\% 20$ that, milk\%20production\%20in\%20the\%20region. Accessed: 06/04/2021.

Kawadia, G. and Tiwari, E. (2017). Understanding climate change in Indore district: an empirical investigation of trends and shifts. Amity Journal of Economics. 2(1): 64-78.

Lowry, O.H., Rosebrough, N.J., Farr, A.L. and Randall, R.J. (1951). Protein measurement with Folin-Phenol reagent. Journal of Biological Chemistry. 193: 265-276.

Matoli, S., Audarya, S.D., Chhabra, D., Singh, M., Chaubey, K., Gupta, S., Sikrodia, R., Jatav, G.P. and Singh, S.V. (2018). Serological, microscopical and molecular examinations of cow milk samples for diagnosis of Paratuberculosis at Mhow of Madhya Pradesh in India. InternationalJournal of Current Microbiology and Applied Sciences. 7(11): 2153-2162.

Nielsen, S.S., Toft, N. and Okura, H. (2013). Dynamics of specific anti-Mycobacterium avium subspecies paratuberculosis antibody response through age. PLoS ONE. 8(4): e63009.

Pierce, E.S. (2018). Could Mycobacterium avium subspecies paratuberculosis cause Crohn's disease, ulcerative colitis... and colorectal cancer? Infectious Agents Cancer. 13(1): $1-6$. 
Pradere, J.P. (2014). Links between livestock production, the environment and sustainable development. Revue Scientifique Et Technique Office International des Epizooties. 33(3): 765-781.

Radostits, O.M., Gay, C.C., Blood, D.C. and Hinchcliff, K.W. (2000). Veterinary medicine, a textbook of the diseases of cattle, sheep, pigs, goats and horses, $9^{\text {th }}$ edition. London: Saunders $1877 \mathrm{pp}$.

Rathnaiah, G., Zinniel, D.K., Bannantine, J.P., Stabel, J.R. and Grohn, Y.T. (2017). Pathogenesis, molecular genetics and genomics of Mycobacterium avium subspecies paratuberculosis, the etiologic agent of Johne's disease. Frontiers in Veterinary Science. 4: 187.

Rhodes, G., Richardson, H., Hermon-Taylor, J., Weightman, A. and Higham, A. (2014). Mycobacterium avium subspecies paratuberculosis: Human exposure through environmental and domestic aerosols. Pathogens. 3: 577-595.

Salem, M., Heydel, C., El-Sayed, A., Ahmed, S.A., Zschock, M. and Baljer, G. (2013). Mycobacterium avium subspecies paratuberculosis: an insidious problem for the ruminant industry. Tropical Animal Health Production. 45(2): 351-366.

Sevilla, I, Singh, S.V., Garrido, J.M., Aduriz, G., Rodriguez, S., Geijo, M.V., Whittington, R.J., Saunders, V., Whitlock, R.H. and Juste, R.A. (2005). Molecular typing of Paratuberculosis strains from different hosts and regions. Revue scientifique et technique Office International des Epizooties. 24: 1061-1066.

Sharma, S., Gautam, A., Singh, S.V., Chaubey, K.K., Mehta, R., Gupta, S., Sharma, M., Rose, M.K. and Jain, V.K. (2020). Prevalence of Mycobacterium avium subspecies paratuberculosis (MAP) infection in suspected buffaloes and cattle reporting at Veterinary University in India. Comparative Immunology, Microbiology and Infectious Diseases. 73: 101533.
Singh, A.V., Chauhan, D.S., Singh, S.V., Kumar, V. and Singh, A. (2016a). Current status of Mycobacterium avium subspecies paratuberculosis infection in animals and humans in India: What needs to be done? Indian Journal of Medical Research. 144: 661-771.

Singh, S.V., Agrawal, N.D., Kumar, N., Gupta, S. and Chaubey, K.K. (2014). Screening of human population for type 1 diabetes and Mycobacteriumavium subspecies paratuberculosis from Chhatarpur district of Madhya Pradesh. Advances in Animal and Veterinary Sciences. 2(11): 612-619.

Singh, S.V., Audarya, S.D., Singh, M., Stephen, B.J., Chhabra, D., Chaubey, K.K., Gupta, S., Sahzad, Pachoori, A., Jayaraman, S., Aseri, G.K., Sohal, J.S., Bhatia, A.K. and Dhama, K. (2016b). Development of new indigenous dotELISA kit as sensitive field-based herd screening test for the diagnosis of Johne's disease in the domestic buffalo population. Asian Journal of Animal and Veterinary Advances. 11(1): 44-52.

Sun, W.W., Lv, W.F., Cong, W., Meng, Q.F. and Wang, C.F. (2015). Mycobacterium avium subspecies paratuberculosis and bovine leukaemia virus seroprevalence and associated risk factors in commercial dairy and beef cattle in northern and northeastern China. BioMed Research International. 1-7.

VIKASPEDIA. (2021). $20^{\text {th }}$ livestock census. Available: https:// vikaspedia.in/agriculture/agri-directory/reports-andpolicy-briefs/20th-livestock-census. Accessed: 06/04/2021.

Whittington, R., Donat, K., Weber, M.F., Kelton, D. and Nielsen, S.S. (2019). Control of paratuberculosis: who, why and how. A review of 48 countries. BMC Veterinary Research. 15(198): 1-29. 